\title{
Village Original Income Increase Strategy Through Local Potential Developmentin Burno Village, Senduro Lumajang East Java Indonesia
}

\author{
moh. hudi setyobakti ${ }^{1}$, ratna wijayanti daniar paramita ${ }^{2}$, noviansyah rizal $^{3}$, istifadah ${ }^{4}$ \\ STIE Widya Gama Lumajang ${ }^{1,2,3}$, Universitas Jember ${ }^{4}$ \\ \{hudisetyobakti@gmail.com¹,pradnyataj@gmail.com², noviansyah.rizal@gmail.com³ \\ istifadah1966@gmail.com ${ }^{4}$,
}

\begin{abstract}
The purpose of this research is to analyze how to develop the potential of the village so that it can provide a source of village income. This research uses qualitative methods with a participatory approach. Resource persons in this study was determined by means snowball, so come by several speakers who considered sufficiently representative. Data processing with a SWOT analysis approach. The results showed that Burno village has the main potential in the form of bananas, especially kirana bananas. Potential supporters are village tourism. So that the design developed by the village is the development of the potential of Burno Village to become a banana center in the form of a banana agro-tourism concept with cultivation modeling, post-harvest and tourism education. Supporting this activity is through the support of naturebased tourism (sundari area, waterfall and bamboo forest) and its surroundings as well as education on the cattle farming sector and local culture.
\end{abstract}

Keywords: Local Potential, Banana Agro-Tourism , Strategic Management, SWOT

\section{Introduction}

Burno Village is one of the villages located at the foot of Mount Semeru, precisely in Lumajang Regency, Senduro District. This location on the slopes of a mountain makes Burno one of the villages that has cool air and a typical highland topography. Burno Village is known as an area dominated by plantation areas and some of the areas are included in the Bromo Tengger Semeru National Park (TNBTS) area. This condition makes Burno has a topography of the area that is suitable for plantations, livestock and of course forest tourism. The vision of the village government, in this case the village head, as expressed directly by the village head, is that he wants to turn Burno into a local potential-based development area that has an impact on improving the welfare of the community.

The development of potential in the village is one of the village strategies in improving village welfare in a sustainable manner [1]. Development in a participatory way by involving community members will foster a sense of community empathy so that the community will be able to preserve together [2], as well as community-based tourism management [3]. Management with a participatory approach will be able to provide aspects of economic 
improvement through empowerment community [4]. Based on this, the research was conducted in order to identify the real potential in Burno village. The results of the research are then used as study material or academic texts for the government in preparing village planning.

\section{Method}

This research is a type of community-based qualitative research carried out in a participatory manner. The technique used in determining informants is the snowball technique. The initial informant is the party who is considered to understand the characteristics of the area, in this case the Village Head. Participants develop along with the information previously obtained, thereby enriching the data obtained. So that the participants involved as informants include the Village Head, Village Officials, Bumdesa Management and Farmer Groups. Testing the validity of the data that has been obtained is carried out by means of a FGD (Focus Group Discussion) mechanism by bringing together previous informants to strengthen the decision-making process. The FGD also invited several additional resource persons who were deemed to be able to provide additional information which was expected to enrich supporting information, including MSMEs, LMDH and the Cattle Breeder Group. FGD results, which is the material data analysis with SWOT analysis approach until a few alternative strategies that will be implemented. The next stage is a special FGD with the village government, to obtain input on alternative strategies that will be taken and outlined in the village government's strategic plan. Research using the swot analysis approach can help map potential and problems as well as opportunities and challenges faced by business people, especially small businesses [5]. Based on this, business actors and other organizations, including health, can make strategies in facing threats and taking existing opportunities [6] [7].

\section{Results and Discussion}

\subsection{General Description}

Burno village is one of the villages located in Senduro Lumajang district . A procession traveled from Lumajang district capital is $21 \mathrm{~km}$. To the west is Bromo Tengger Semeru National Park. To the east is Senduro Village, to the South is Jambekumbu Village, Pasrujambe. To the north is the village of tepus cages. The Burno Village area is one of the mainstay banana chips production centers in Lumajang Regency. The area of Burno Village is $40,72 \mathrm{~km}$. which is divided into agricultural land covering an area of $594.36 \mathrm{ha}$, yards and buildings covering an area of 243.26 ha, and other land covering an area of 3234.8 ha. From the population registration data collected in 2016, the total population of Burno village reached 5395 people with a male gender ratio of 2771 people and 2624 women. The number of households in Burno Village is 1232 families. The average number of family members is 4 . The population density in Burno Village is 132 people / $\mathrm{km} 2$. The village area consists of 6 hamlets, namely Krajan 1 and 2 hamlets, Tugu hamlet, Mlambing hamlet, Karanganyar hamlet, Gondang hamlet [8]. 


\subsection{Village Potential}

Based on the results of data mining, some information was obtained about the potential in Burno village. The main potential in Burno village is plantations. The dominating plantation products are mas kirana banana and several other types of banana. Bananas are a characteristic of Burno Village, because the majority of the population owns banana gardens. Other products include coffee, cloves, and other crops. Livestock is also one of the sources of income for Burno villagers. The dominant farms are dairy cows, etawa goats. The most cattle breeding areas are located in the Perhutani area, because they are close to the source of animal feed. Precisely in the Karang Anyar hamlet.

Burno Village also has several areas that have become tourist objects and there are some that are still in the form of undeveloped potential. The tourist area is the rest area of Siti Sundari. Meanwhile, what has not been optimized are the Sobyok and Watusilo waterfall areas. The rest area and waterfall area are in the Perhutani area. Another tourism potential is the bamboo forest, where the bamboo forest is a support for village water sources, and is located in the village treasury land area. In addition to natural tourism, Burno has a variety of local wisdoms, including the culture of banana rice, batik damaran, ludruk art and traditional grass-carrying vehicles.

Potential resources of others, including the local institutional villages. Local institutions that already exist in the Burno village area . These institutions are institutions that carry out activities in the form of services to the community. Some of these institutions are independent and some are established by the Village Government. Some of these institutions include Village-Owned Enterprises (Bumdesa), Farmer Groups, Cattle Breeders Groups, Association of Drinking Water Users (HIPPAM), Youth Organizations, MSMEs, Financial Management Units (UPK u ) and Forest Village Community Institutions (LMDH).

\subsection{Village Potential Analysis based on SWOT Analysis}

\section{a) Strength}

The local potential of Burno Village that stands out is bananas. In terms of the amount of production it is quite abundant. Burno village branding is known as a producer of mas kirana bananas, and one of the export suppliers of kirana banana. Currently, 70 banana species have been identified, and they have been developed, meaning that the diversity of types they have is more valuable than other locations. The total area of land managed by banana farmers is more than 60 hectares. This means that the potential for harvest is quite abundant throughout the year.

Burno Village is also one of the villages that has tourism potential locations, this is due to the natural potential that supports the existing local wisdom culture. The Siti Sundari area as a rest area is a pleasant area for a relaxing family vacation. Besides the Burno rest area, it also has the potential of Sobyok and Watusilo waterfalls. The three locations are in the Perhutani area, in a forest area with cool air. Burno Village also has a bamboo forest area located on the village treasury land. This forest is sustainable because it supports a spring that is used by the village community. Apart from the potential for natural tourism, there is a culture of local wisdom that can be valuable, both from educational and other aspects. Sego gedang, community alternative food as an additional source of carbohydrates from a combination of bananas and rice, damaran batik business, as a typical Burno batik, burno typical Ludruk and non-engine traditional vehicles for transporting grass which can be used as an opportunity for 
the general public to ride it. An integrated dairy farm can also be of value to sell educational tours for the wider community.

Local institutions that have been formed and become a support for the village government can be optimized as partners for the village government. Bumdesa functions as a village capital management institution, of course, has a strategic role in optimizing the economic potential of the village [9] . Other institutional roles of farmer groups, HIPPAM, Karang Taruna, UPKu, LMDH are partners who together can drive the village economy. Farmers' Groups as institutions that carry out agricultural management, especially bananas, are a potential force that provides output of banana harvest, HIPPAM with water resources management, Karangtaruna with its youth human resources, UPKu with village micro credit management and LMDH as the party managing the Siti Sundari area, entrepreneurs Micro (UMKM) which has been concentrating on micro-business activities in villages, especially banana and batik chips entrepreneurs, are all forces that can support the economy together with the village government.

\section{b) Weakness}

The existing agricultural potential, especially bananas, still has several problems in its management. Kirana banana products produced by farmers in general are not all well marketed. Farmers sell banana products to traders at a price that is not good enough, which often causes losses to farmers. In addition, the products of burno village banana that are sold outside the city and abroad are limited in certain quantities. Because there are competitors with imported banana products. This causes banana farmers to often experience difficulties in selling the remaining unabsorbed product. In terms of processed banana products, they also experience similar conditions, apart from the limitations of banana processing innovation . Processed bananas in Burno Village are limited to types of chips, sale and syrup.

Weaknesses in tourism potential, where this potential has several problems including, the status of tourist sites that make the development less than optimal, lack of maintenance of facilities, supporting facilities for the tourist attractions. The area revitalization activity has been accompanied by the University of Jember and NGOs in Lumajang, but the sustainability aspect has not been maximally implemented. The land is located in the Perhutani area, in this case it is in another legal subject area (Perhutani). The main problem with the potential of the waterfall is the difficult road access. The potential of the waterfall is constrained by infrastructure as access to the waterfall location. The road cannot be passed directly by fourwheeled vehicles, and it is difficult to pass by two- wheeled vehicles, so visitors have to walk one kilometer. Besides that, it is also in the territory of Perhutani law. Constraints Another particularly in the waterfall area sobyok contained waste contamination of cattle, which was a discharge line on cow dung by society. Meanwhile, at the location of the Pandayangan bamboo forest, the problem faced by this potential is that it has not been fully developed. both by the village government and the Burno village community. The supporting facilities for the location are not yet available.

Weaknesses in the institutional aspect vary according to the type of institution. Bumdesa is a young institution, established in 2019 and in 2020 starting to operate. Some weaknesses (1) Completeness organization yet (AD ART, administration and the like), (2) Plan for business development yet, (3) Perdes equity participation has not been arranged , (4) Plan of financial management have not been prepared , (5) Means and infrastructure does not yet have (office is not yet available and other equipment), (6) does not have adequate capacity . Meanwhile, other weak points are weak points in the operational management aspects of institutions, 
finance and human resource crises as well as less than optimal inter-institutional relations, tend to be sectoral egos.

\section{c) Opportunity}

The portrait of the village's potential, in the fields of agriculture, tourism and village local institutions, has an opportunity if it is managed in an integrated manner and has the potential to have an impact on the development of the village economy [10]. This integration can be realized by making the village an agro-based tourism destination, especially banana farming from upstream to downstream with adequate natural tourism support [11]. This concept can later be managed by local village institutions with a partnership pattern where the central role is in Bumdesa [12]. The partnership pattern between Bumdesa and local village institutions will provide a good reciprocal relationship and are mutually beneficial, so that each can play a role in accordance with their respective fields.

\section{d) Threat}

The rural tourism sector in this period of 5 five years has experienced rapid development. Since the enactment of law number 6 of 2014 concerning villages, especially regarding village authority, villages have been encouraged to exercise their rights in optimizing their potential to be appointed so that they can impact community welfare and provide income opportunities for the village. Village fund support from the Central Government provides a stimulus for the village to do that. This means that when many villages have initiated village tourism, they will certainly become competitors for the Burno Village government.

\subsection{Strategy for Increasing Village Original Income (PAD) through Potential Development}

Based on the analysis of village potential, an alternative in the framework of a strategy to increase village income is to design the village of Burno as a tourism village based on banana agro-tourism. This is in line with the vision and mission of the head of the village where one village membranding Burno as banana village mas ray. Design Development of the potential of Burno Village to become a banana center in the form of a banana agro-tourism concept with cultivation modeling, post harvest and tourism education. Support for this activity through the support of nature-based tourism (sundari area, waterfall and bamboo forest) and its surroundings as well as education on the cattle farming sector and local culture. In responding to future challenges, this design must provide added value, both in terms of uniqueness, uniqueness, service to existing competition. The idea of the results of the FGD with the Village Government regarding the banana agro-tourism village is as follows: 


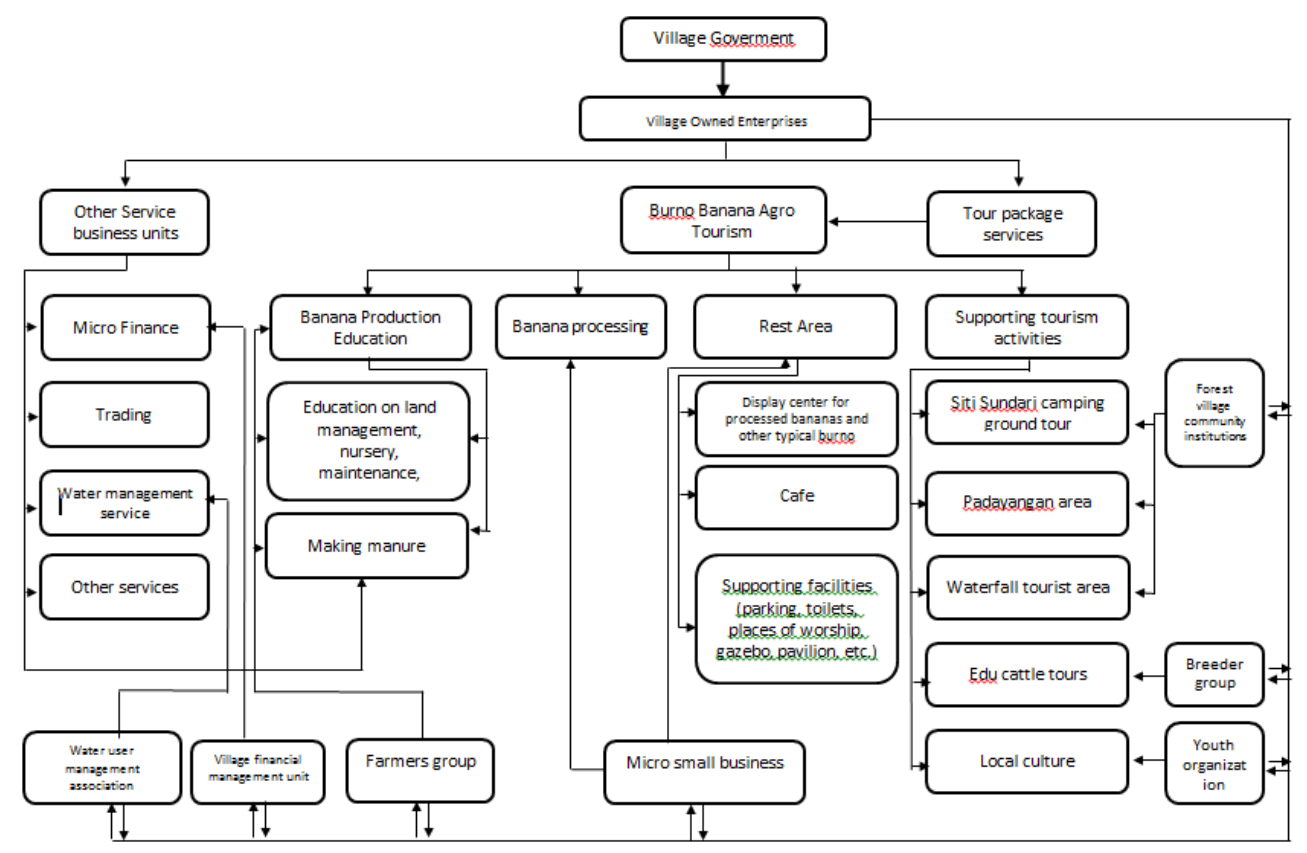

Fig. 1. Burno Village Agro-tourism Development Plan Design

The explanation of the above chart is integrated in the form of Bumdesa activities as a village economic institution that is tasked with carrying out activities as well as coordinating the Banana Agro-tourism village development program in Senduro village. Bumdesa was chosen because it is an institution that is legally valid and recognized, and is the only institution entitled to receive capital funds from the Village Government.

a. Management management will technically be carried out by the B umdesa by becoming part of the B umdesa business unit. The pattern is B umdesa partners with related groups, including:

1. Partnering with banana farmer groups, where the farmer groups act as providers of educational space for mas kirana banana cultivation

2. Partnering with UMKM as a provider of post-harvest processing education and Bumdesa as a marketing agency

b. The village prepares supporting facilities and infrastructure in the form of road access to banana agro-tourism locations, rest areas and parking lots that are strategically located and as information centers related to Kirana banana education, camping ground, and padayangan tourism.

c. Bumdesa prepares tour visit packages (tour flow ) in the form of packages, and prepares special transportation that will be used by visitors.

d. At the Kirana banana educational location, literacy facilities are provided that contain information on Kirana bananas (types, varieties, nurseries, planting, harvest, pests, processed products, marketing, etc.). In addition, a product processing center and outlet, café and supporting facilities are provided.

e. Provision of a rest area, as a means of introducing burno nature, local products, culture and the main idea of education for various kinds of burno banana preparations. The rest area fulfills the aspects of a comfortable resting place, there is a cafe with the main product 
processed bananas, natural views, toilets, places of worship and ample parking space. This rest area can be integrated with the Sundari area or it can be separated

f. Supporting Tourism

1. Siti Sundari area is prepared as a rest area and camping ground facilities. Managers in this case bumdes or villages provide tents for visitors to rent. Apart from that, other facilities are being constructed, such as an out bond, a garden, a 24- hour security post and a bathroom and a place for prayer. The management of the siti sundari area is carried out by LMDH.

2. Padayangan is prepared to support tourism access to agro-tourism sites with adequate infrastructure.

3. Waterfall tourism, is also a supporting tour that supports the introduction of burno as a banana agro-tourism location.

4. The introduction of local culture, local wisdom is also a supporting sector that can be introduced and has its own uniqueness. Among them are ludruk and grass transport cars (a typical burno formula). The concept is to be a special event event.

5. This activity is a strategic partnership with local institutions such as LMDH, Karangtaruna, UMKM while Bumdesa is at the organizer level.

g. The design of village development to become a banana agro-based tourism village, integrated with bumdesa business management, so that Bumdesa is used as the main institutional instrument. This concept will run in parallel with the development of other bumdesa businesses, so that Bumdesa as the main supporting institution will be able to carry out a healthy business concept.

h. Preparing Bumdesa as the leading sector in agro-tourism management requires strengthening management and operations so that it can continue to maintain existence and survival, so that in this program, it also prepares bumdesa to become village economic managers by strengthening the bumdesa business sector besides agro-tourism, including the microfinance sector, clean water services, partnering with existing local institutions, trade and other sectors with a partnership pattern such as with MSMEs.

\subsection{Government's Strategic Plan in Realizing Banana Agrotourism Village}

The strategic plan of activities has been compiled over a period of five years from 2020 . This is in the framework of achieving the vision of developing Burno village into a banana agro-tourism area. The stages are arranged annually which are an integral part of achieving this vision.

\section{a) First Year}

1. Strengthening the capacity of the village planning preparation RKPDesa and APBDesa

2. Integrating the program into the village development system

3. Availability of access to information in the location of agro-tourism in Mlambing Village

4. Availability of office space for Bumdesa managers

5. Bumdesa has the capacity in preparing business plans

\section{b) Second Year}

1. Provision of road access to the agro location properly

2. Enrichment of banana plant species and expansion of land 
3. Availability of educational space for the management of processed banana production

4. Revitalization of supporting tourism areas in the Siti Sundari area

5. Revitalization of padanyangan areas to be clean and healthy as well as providing access to information

6. Revitalization of dairy farming education is more feasible and healthier and provides access to information

7. Increasing the capacity of MSMEs in business management (production, management and finance), especially banana processing through training

8. Increase the capacity of UPKu as a bumdesa partner in financial management and credit management

9. Development of strategic partnerships between Bumdesa and existing local institutions

10. Prepare SOP for bumdesa management in managing activities

\section{c) Third Year}

1. The availability of facilities and infrastructure at the agro location in the form of information and education places, practice places, rest rooms)

2. Availability and readiness of human resources for agro tour guides

3. Adequacy of educational room infrastructure for banana processing

4. Provision of infrastructure and facilities at the location of the padanyangan area as supporting tourism

\section{d) Fourth Year}

1. Provision of rest areas with natural views and complete display rooms for bananas and other superior products, parking, and food courts (banana as the main product).

2. Revitalizing the waterfall area which is beautiful, natural and healthy

3. The availability of easy road access to the waterfall location

4. The availability of local cultural facilities in the form of equipment

5. Building a partnership framework for Bumdesa with external institutions

e) Fifth Year

1. Provision of completeness of other rest areas, places of worship and toilets

2. Optimizing the development of access to the location of the waterfall

3. Promotion of local village culture

4. Strengthening strategic partnerships with external agencies

\section{Conclusions}

The agro-tourism-based village tourism sector is quite prospective to be developed. Village governments are required to be creative in optimizing the potential in their area. The ability to identify the potential and ability to innovate will give birth to the idea of building a creative, unique and distinctive model of the concept of agro-tourism being developed. The appointed managers are expected to be able to manage well and be able to build networks so that the concept that becomes this big idea can be sustainable. 
The local potential-based village development model is an implementation of community empowerment. Therefore, running this model requires a process that is not instantaneous, so that it can really answer problems in a participatory manner. The village government needs to find ways that can optimize the growth of citizen participation, so that the implementation of activities later can run with a sense of community concern for preservation.

\section{References}

[1] et all Manda Putra, "Sustainability analysis of the management of Lake Baru in Buluh Cina Village, Indonesia," Smart Sustain. Built Environ., vol. 7, no. 2, pp. 182-211, 2018.

[2] et all Kasri, "Citizen engagement to sustaining community-based rural water supply in Indonesia," Eletronic Libr., vol. 16, no. 3, pp. 226-288, 2017.

[3] G. Sakitri, "Local community engagement in a festival in Indonesia," Int. J. Cult. Tour. Hosp. Res., vol. 12, no. 1, pp. 29-46, 2018.

[4] et all Sjahza, "Regional economic empowerment through oil palm economic institutional development," Manag. Environ. Qual. An Int. J., vol. 30, no. 6, pp. 1256$1278,2019$.

[5] I. Budi, W. D. Bhayangkara, and I. Fadah, "Identification of Problems and Strategies of the Home-Based Industry in Jember Regency,” Agric. Agric. Sci. Procedia, vol. 9, pp. 363-370, 2016.

[6] M. Barbosa, J. A. Castañeda -Ayarza, and D. H. Lombardo Ferreira, "Sustainable Strategic Management (GES): Sustainability in small business," J. Clean. Prod., vol. 258, 2020.

[7] M. A. Köseoglu, F. Okumus, I. C. Dogan, and R. Law, "Intellectual structure of strategic management research in the hospitality management field: A co-citation analysis," Int. J. Hosp. Manag., vol. 78, no. September, pp. 234-250, 2019.

[8] P. D. Profil Desa Burno, "DATA UMUM DESA 2011 - 2012 pdf." Pemerintah Desa Burno, Lumajang, 2013.

[9] M. H. Setyobakti, "IDENTIFICATION OF BUSINESS ENTERPRISES BUMDES BASED ON SOCIAL AND ECONOMIC ASPECT (Case Study at BUMDes Ijen Lestari Tamansari Village District of Banyuwangi)," JEMA J. Ilm. Bid. Akunt. dan Manaj., vol. 14, no. 02, p. 101, 2018.

[10] H. S. Bakti, "Identifikasi Masalah Dan Potensi Desa Berbasis Indek Desa Membangun (Idm) Di Desa Gondowangi Kecamatan Wagir Kabupaten Malang," Wiga J. Penelit. Ilmu Ekon., vol. 7, no. 1, pp. 1-14, 2018.

[11] T. A. Prabowo, "ANALISIS STRATEGI PENGEMBANGAN KAWASAN AGROPOLITAN KABUPATEN NGANJUK," Media Trend, 2015.

[12] T. Budiarti and I. Muflikhati, "Pengembangan Agrowisata Berbasis Masyarakat Pada Usahatani Terpadu Guna Meningkatkan Kesejahteraan Petani Dan Keberlanjutan Sistem Pertanian,” J. Ilmu Pertan. Indones., vol. 18, no. 3, pp. 200-207, 2013. 